\title{
Antibacterial and Antifungal Activities of Jatropha multifida (Ogege) Sap against Some Pathogens
}

\author{
Michael Niyi Aransiola ${ }^{1}$, Charles Ehikhase ${ }^{2}$, Joy C. Mmegwa \\ ${ }^{3}$ Idris Olayinka Wahab ${ }^{4}$ \\ 1, 2, 4 (Department of Microbiology, Faculty of Science, University of Ibadan, Ibadan, Nigeria) \\ ${ }^{3}$ (Department of Medical Microbiology and Parasitology, College of Medicine, University of Lagos, Nigeria)
}

\begin{abstract}
Jatropha multifida (Ogege) sap was screened for antibacterial and antifungal activities against Pseudomonas aeruginosa, Klebsiella pneumoniae, Staphylococcus aureus, Escherichia coli, Bacillus subtilis, Salmonella typhi and Candidasp. The phytochemical components of Jatropha multifida (Ogege) sap showed the presence of alkaloids, saponin, carbohydrate, phenol and tannins, and the absence of glycosides, flavonoids and steroid. Agar well diffusion and broth dilution methods were used to determine the minimum inhibitory concentration (MIC) and minimum bactericidal concentration (MBC) at concentrations $1050 \mathrm{mg} / \mathrm{ml}$ to $2 \mathrm{mg} / \mathrm{ml}$ (by two fold dilution using sterile distilled water). The result of this study showed that all the organisms were susceptible to the sap. Gram-positive bacteria, Bacillus subtilis and Staphylococcus aureus were found most susceptible with MIC of $4 \mathrm{mg} / \mathrm{ml}$ and $16 \mathrm{mg} / \mathrm{ml}$ respectively, followed by Gram-negative bacteria, Pseudomonas aeruginosa, Escherichia coli and Salmonella typhi with MIC of $66 \mathrm{mg} / \mathrm{ml}$ and Klebsiella pneumoniae, $263 \mathrm{mg} / \mathrm{ml}$, and Candidasp. had MIC of $263 \mathrm{mg} / \mathrm{ml}$. The MBC determination showed that a concentration of $131 \mathrm{mg} / \mathrm{ml}$ and $263 \mathrm{mg} / \mathrm{ml}$ could completely kill Staphylococcus aureus and Bacillus subtilis respectively and $525 \mathrm{mg} / \mathrm{ml}$ could completely kill both Klebsiella pneumoniae and Candidasp. The result of this study suggests that Jatropha multifida (Ogege) sap could be potential source of new antimicrobial agents.
\end{abstract}

Keywords: Antibacterial activity, Antifungal activity, Jatropha multifida (Ogege) sap, Minimum Bactericidal Concentration, Minimum Inhibitory Concentration, Phytochemical components.

\section{Introduction}

Of the world population, about three quarter relies on plants and their extracts for their healthcare [1]. Traditional medicine is an important source of potentially useful new compounds for the development of chemotherapeutic agents [2]. Emergence of pathogenic microorganisms that are resistant/ multi resistant to major class of antibiotics has increased in recent years due to indiscriminate use of synthetic antimicrobial drugs [3]. In addition, high cost and adverse side effects are commonly associated with popular synthetic antibiotics (such as hypersensitivity, allergic reactions, immjunosupression etc.) and are major burning global issues in treating infectious diseases [4]. Although pharmacological industries had produced considerable number of commercial antibiotics time to time but resistance in pathogens towards these drugs too has increased at high rate and mult-drug resistant microorganisms have exacerbated the situation [5]. In the present scenario, there is an urgent and continuous need of exploration and development of cheaper, effective new plant based drugs with better bioactive potential and least side effects. Hence, recent attention has been paid to biologically active extracts and compounds from plant species used in herbal medicines [6]. Antimicrobials of plant origin have enormous therapeutic potential and have been used since time immemorial. They have been proved effective in the treatment of infectious diseases simultaneously mitigating many of the side effects which are often associated with synthetic antibiotics [7]. Positive response of plant based drugs (less/ no side effects) might lies in the structure of the natural products which reacts with toxins and/or pathogens in such a way that less harm is done to other important molecules or physiology of host. It is because of this reason that drug designing studies nowadays have come up as new field of research.

Jatropha multifida (locally called 'Ogege' in some part of Southwest, Nigeria) belong to the family Euphorbiaceae [8], origin uncertain but probably indigenous to Barbados. A very attractive and widely cultivated species throughout the tropics and is commonly known as coral plant or French physic nut [9]. $J$. multifida Linn. is grown as an ornamental plant in north Australia and South east Africa [10], The leaves and latex of $J$. multifida are used medicinally. The leaves are used in scabies: the latex is applied over wounds and ulcer and the oil is used both internally and externally as abortifacient [11]. The bark and leaves are used as medicine for neurodermatitis, itchy skin and skin eczema [12]. The stems were employed as chewing sticks used for dental care in Ekiti state, Nigeria [13].

The objective of study is to investigate the phytochemical component, antibacterial and antifungal activities of Jatropha multifida (Ogege) sap on Pseudomonas aeruginosa, Klebsiella pneumoniae, 
Staphylococcus aureus, Escherichia coli, Bacillus subtilis, Salmonella typhi and Candida sp. and also to determine the minimum inhibitory concentration (MIC) and minimum bactericidal concentration (MBC) of the sap on the test organisms.

\section{Materials and Methods}

\subsection{Collection and Preparation of Samples}

The Jatropha multifida (Ogege) sap was collected from the Department of Microbiology, University of Ibadan, Ibadan inside a sterile sample bottle after surface sterilization of the tip end of the tree branch with $75 \%$ ethanol and cotton wool. The tip end was tilted and broken, and the sap was allowed to drain into the bottle. Hand contamination was carefully avoided during collection. The sample was lyophilized and weighed. Stock of $1050 \mathrm{mg} / \mathrm{ml}$ was then prepared in distilled water.

\subsection{Sources and Maintenance of Organisms}

Pure cultures of Pseudomonas aeruginosa, Klebsiella pneumoniae, Staphylocccus aureus, Escherichia coli, Salmonella typhi and Candida sp. were collected from Medical Microbiology

Laboratory, University College Hospital, Ibadan and pure culture of Bacillus subtilis was collected from the Department of Microbiology, University of Ibadan, Ibadan, Oyo State and were subcultured on agar slant (Nutrient Agar for bacteria and Potato Dextrose Agar for fungi). Twenty-four hour old cultures were prepared for use at each time.

\subsection{Phytochemical Screening of the Sap}

Then the screening of the plant sap was carried out according to the method described by [14] for the purpose of detecting active components like glycosides, phenol and tannins, alkaloids, steroids, saponins, carbohydrate, and flavonoids.

\subsection{Culture Media}

Mueller-Hinton Agar was prepared according to the manufacturer's instruction, autoclaved and dispensed at $20 \mathrm{ml}$ per plate in $12 \times 12 \mathrm{~cm}$ Petri dishes. Set plates were incubated overnight to ensure sterility before use.

\subsection{Antimicrobial Bioassay}

Suspension of micro-organisms was made in sterile normal saline and adjusted to 0.5 Macfarland standard $\left(10^{8} \mathrm{Cfu} / \mathrm{ml}\right)$ [15]. From the sap stock of $1050 \mathrm{mg} / \mathrm{ml} \mathrm{sap}$, two-fold serial dilution with distilled water to obtain concentrations $525 \mathrm{mg} / \mathrm{ml}, 263 \mathrm{mg} / \mathrm{ml}, 131 \mathrm{mg} / \mathrm{ml}, 66 \mathrm{mg} / \mathrm{ml}, 33 \mathrm{mg} / \mathrm{ml}, 16 \mathrm{mg} / \mathrm{ml}, 8 \mathrm{mg} / \mathrm{ml}, 4 \mathrm{mg} / \mathrm{ml}$ and $2 \mathrm{mg} / \mathrm{ml}$. Each labeled medium plate was uniformly inoculated with a test organism by using a sterile cotton swab rolled in the suspension to streak the plate surface in a form that lawn growth can be observed. A sterile cork borer of $7 \mathrm{~mm}$ diameter was used to make wells on the medium. $0.1 \mathrm{ml}$ of the various extract concentration were dropped into each, appropriate labeled well $[16,17]$. Water was tested neat for each organism. The Mueller Hinton Agar plates were incubated at $37^{\circ} \mathrm{C}$ for 24 hours. Antimicrobial activity was determined by measuring the diameter of zones of inhibition $(\mathrm{mm})$ produced after incubation. O.05\% of Ciprofloxacin was used as control [15].

\subsection{Determinatiion of Minimum Inhibitory Concentration (MIC)}

To measure the MIC values, the sap stock and various concentrations of the stock, $1050 \mathrm{mg} / \mathrm{ml}$, $525 \mathrm{mg} / \mathrm{ml}, 263 \mathrm{mg} / \mathrm{ml}, 131 \mathrm{mg} / \mathrm{ml}, 66 \mathrm{mg} / \mathrm{ml}, 33 \mathrm{mg} / \mathrm{ml}, 16 \mathrm{mg} / \mathrm{ml}, 8 \mathrm{mg} / \mathrm{ml}, 4 \mathrm{mg} / \mathrm{ml}$ and $2 \mathrm{mg} / \mathrm{ml}$ were assayed against the test bacteria. The minimum inhibitory concentration was defined as the lowest concentration able to inhibit any visible bacterial growth $[18,17]$.

\subsection{Determination of Minimum Bactericidal Concentration (MBC)}

Equal volume of the various concentrations of the sap and Mueller Hinton broth were mixed in microtubes to make up $0.5 \mathrm{ml}$ of solution (1:4). $0.5 \mathrm{ml}$ of McFarland standard of the organism suspension was added to each tube [17]. The tubes were incubated aerobically at $37^{\circ} \mathrm{c}$ for $24 \mathrm{~h}$. Two control tubes were maintained for each test batch. These include tube-containing extract without inoculum and the tube containing the growth medium and inoculum. The MBC was determined by sub-culturing the test dilution on Mueller Hinton Agar and further incubated for $24 \mathrm{~h}$. The highest dilution that yielded no single bacterial colony was taken as the Minimum bactericidal Concentration [19]. This was carried out on the Gram-positive organisms (Bacillus subtilis and Staphylocccus aureus) being highly sensitive, Klebsiella pneumoniae, and Candida sp. 
3.1. Phytochemical Screening of the Sap

\section{Results}

TABLE 1 shows the phytochemical screening of the sap of Jatropha multifida (Ogege). The result indicates the presence of carbohydrate, phenol and tannins, saponins, and alkaloids, and the absence of flavonoids, glycosides, and steroids.

Table 1: Phytochemical Screening of the Jatropha multifida (Ogege) Sap

\begin{tabular}{ll}
\hline \multicolumn{1}{c}{ Phytochemical component } & Sap \\
\hline Glycosides & - \\
Alkaliods & + \\
Flavonoids & - \\
Phenol and tannins & + \\
Saponins & + \\
Steroids & - \\
Carbohydrate & +
\end{tabular}

$+=$ present; $-=$ absent

\subsection{Antimicrobial Bioassay of the Jatropha multifida (Ogege) Sap}

TABLE 2 shows the zones of inhibitions (mm) of Jatropha multifida (Ogege) sap on Pseudomonas aeruginosa, Klebsiella pneumoniae, Staphylococcus aureus, Escherichia coli, Bacillus subtilis, Salmonella typhi and Candida sp. at concentrations $1050 \mathrm{mg} / \mathrm{ml}, 525 \mathrm{mg} / \mathrm{ml}, 263 \mathrm{mg} / \mathrm{ml}, 131 \mathrm{mg} / \mathrm{ml}, 66 \mathrm{mg} / \mathrm{ml}, 33 \mathrm{mg} / \mathrm{ml}, 16 \mathrm{mg} / \mathrm{ml}$, $8 \mathrm{mg} / \mathrm{ml}, 4 \mathrm{mg} / \mathrm{ml}$ and $2 \mathrm{mg} / \mathrm{ml}$, O.O5\% of Ciprofloxacin as control and water (neat).. The control had a lesser antimicrobial effect on the tested organisms than the Jatropha multifida (Ogege) sap except for Pseudomonas aeruginosa. Water had no antimicrobial effect against all the test organisms.

Table 2: Antimicrobial Bioassay of the Jatropha multifida (Ogege) Sap on the Test Organisms Test Organisms $\quad$ Zones of Inhibitions ( $\mathrm{mm}$ )

\begin{tabular}{|c|c|c|c|c|c|c|c|c|c|c|c|c|}
\hline & $\mathbf{A}$ & B & $\mathrm{C}$ & D & $\mathbf{E}$ & $\mathbf{F}$ & G & $\mathbf{H}$ & $\mathbf{I}$ & $\mathbf{J}$ & Cip & $\mathbf{W}$ \\
\hline Pseudomonas aeruginosa & 16 & 12 & 11 & 10 & 8.5 & - & - & - & - & - & 26.5 & - \\
\hline Escherichia coli & 14 & 12.5 & 11 & 10.5 & 9 & - & - & - & - & - & 11 & - \\
\hline Salmonella typhi & 16.5 & 15 & 11 & 10 & 9.5 & - & - & - & - & - & 8.5 & - \\
\hline Klebsiella pneumoniae & 18.5 & 14.5 & 8.5 & - & - & - & - & - & - & - & 13 & - \\
\hline Staphylococcus aureus & 20 & 16.5 & 14 & 13 & 12 & 11 & 9.5 & - & - & - & - & - \\
\hline Bacillus subtilis & 18 & 16.5 & 13.5 & 12.5 & 12 & 11 & 10 & 9.5 & 8.5 & - & 14 & - \\
\hline Candida sp. & 13 & 9 & 8 & - & - & - & - & - & - & - & - & - \\
\hline
\end{tabular}

$A=1050 \mathrm{mg} / \mathrm{ml}, B=525 \mathrm{mg} / \mathrm{ml}, C=263 \mathrm{mg} / \mathrm{ml}, D=131 \mathrm{mg} / \mathrm{ml}, \mathrm{E}=66 \mathrm{mg} / \mathrm{ml}, \mathrm{F}=33 \mathrm{mg} / \mathrm{ml}, \mathrm{G}=16 \mathrm{mg} / \mathrm{ml}$, $\mathrm{H}=\mathbf{8 m g} / \mathrm{ml}, \mathrm{I}=\mathbf{4 m g} / \mathrm{ml}, \mathbf{J}=\mathbf{2 m g} / \mathrm{ml}$, Cip = Ciprofloxacin, $W=$ Water.

3.3. Minimum Inhibitory Concentration (MIC) of the Jatropha multifida (Ogege) Sap on the Test Organisms

TABLE 3 shows the minimum inhibitory concentration (MIC) of the Jatropha multifida (Ogege) sap on the test organisms. All the Gram-negative bacteria had the same MIC of $66 \mathrm{mg} / \mathrm{ml}$ except Klebsiella pneumoniae which had higher MIC of $263 \mathrm{mg} / \mathrm{ml}$ equal to the MIC of the Candida sp. but Gram-positive bacteria had a lower MIC with Staphylococcus aureus having MIC of $16 \mathrm{mg} / \mathrm{ml}$ and Bacillus subtilis having MIC of $4 \mathrm{mg} / \mathrm{ml}$.

Table 3: Minimum Inhibitory Concentration (MIC) of the Jatropha multifida (Ogege) sap on the Test Organisms

\begin{tabular}{|c|c|c|c|c|c|c|c|c|c|c|}
\hline \multirow[t]{2}{*}{ Test Organisms } & \multicolumn{10}{|c|}{ Minimum Inhibitory Concentration (MIC) (mg/ml) } \\
\hline & $\mathbf{A}$ & B & $\mathbf{C}$ & D & $\mathbf{E}$ & $\mathbf{F}$ & G & $\mathbf{H}$ & I & $\mathbf{J}$ \\
\hline Pseudomonas aeruginosa & - & - & - & - & $*$ & + & + & ++ & ++ & ++ \\
\hline Escherichia coli & - & - & - & - & $*$ & + & + & ++ & ++ & ++ \\
\hline Salmonella typhi & - & - & - & - & $*$ & + & + & ++ & ++ & ++ \\
\hline Klebsiella pneumoniae & - & - & $*$ & + & + & ++ & ++ & ++ & ++ & ++ \\
\hline Staphylococcus aureus & - & - & - & - & - & - & $*$ & + & + & ++ \\
\hline Bacillus subtilis & - & - & - & - & - & - & - & - & $*$ & + \\
\hline Candida sp. & - & - & $*$ & + & + & ++ & ++ & ++ & ++ & ++ \\
\hline
\end{tabular}

$A=1050 \mathrm{mg} / \mathrm{ml}, B=525 \mathrm{mg} / \mathrm{ml}, C=263 \mathrm{mg} / \mathrm{ml}, D=131 \mathrm{mg} / \mathrm{ml}, \mathrm{E}=66 \mathrm{mg} / \mathrm{ml}, \mathrm{F}=33 \mathrm{mg} / \mathrm{ml}, \mathrm{G}=16 \mathrm{mg} / \mathrm{ml}$, $\mathrm{H}=8 \mathrm{mg} / \mathrm{ml}, \mathrm{I}=4 \mathrm{mg} / \mathrm{ml}, \mathrm{J}=2 \mathrm{mg} / \mathrm{ml}$. - = no growth, * = MIC, + = little growth, ++ = dense growth. 
3.4. Minimum Bactericidal Concentration (MBC) of the Jatropha multifida (Ogege) Sap on the Test Organisms

TABLE 4 shows the minimum inhibitory concentration of the Jatropha multifida (Ogege) sap on the test organisms. The Gram-positive bacteria had the lowest MBC with Staphylococcus aureus having the MBC of $131 \mathrm{mg} / \mathrm{ml}$ and Bacillus subtilis having the MBC of $263 \mathrm{mg} / \mathrm{ml}$. Klebsiella pneumoniae and Candida sp. had the same $\mathrm{MBC}$ of $525 \mathrm{mg} / \mathrm{ml}$.

Table 4: Minimum Bactericidal Concentration (MBC) of the Jatropha multifida (Ogege) sap on the Test Organisms

\begin{tabular}{cc}
\hline Test Organisms & Minimum Bactericidal Concentration (MBC) \\
\hline Pseudomonas aeruginosa & ND \\
Escherichia coli & ND \\
Salmonella typhi & ND \\
Klebsiella pneumoniae & $525 \mathrm{mg} / \mathrm{ml}$ \\
Staphylococcus aureus & $131 \mathrm{mg} / \mathrm{ml}$ \\
Bacillus subtilis & $263 \mathrm{mg} / \mathrm{ml}$ \\
Candida sp. & $525 \mathrm{mg} / \mathrm{ml}$ \\
\cline { 2 - 2 } determined. &
\end{tabular}

\section{Discussion}

The result of this study showed that Jatropha multifida (Ogege) sap have varied antibacterial and antifungal activities against the tested organisms (TABLE 3). The ability of the sap to have effect on both the Gram-positive and Gram-negative bacteria suggests that the sap of this plant is broad spectrum in activities. This correlates with the observation of previous workers that plants contain substances that are antimicrobial [20]. The sap was active against both the Gram-positive and Gram-negative organisms with better activity against the Gram-positive organisms. This is consistent with findings from other authors that Gram negative bacteria are usually more resistant to antimicrobial agents than Gram positive bacterial species [21, 22] and this susceptibility differences between Gram-positive and Gram-negative bacteria may be due to cell wall structural differences between these classes of bacteria. The Gram-negative bacteria cell wall outer membrane appears to act as a barrier to many substances including synthetic and natural antibiotics [23]. There was also activity observed against Candida sp. although lower than the bacteria (TABLE 3). Klebsiella pneumoniae had the same MIC and MBC with the Candida sp. (TABLE 3 and 4) but little different exist in their zones of inhibitions (TABLE 2) which could mean that Klebsiella pneumoniae ( having higher zones) was a little beat more susceptible compare to the Candida sp. This follows the same trend with the work of [24] that bacteria were more sensitive to his citrus extracts than were the fungi. The lower MIC of Bacillus subtilis $(4 \mathrm{mg} / \mathrm{ml})$ as compare to that of Staphylococcus aureus $(16 \mathrm{mg} / \mathrm{ml})$ (TABLE 3) could be attributed to the fact that the Bacillus subtilis is from environmental origin while the Staphylococcus aureus is a clinical isolate which could have acquired some resistance level to antibiotics and even, Bacillus subtilis could quickly switch into dormancy (spore formation) due to the presence of antibacterial agents. But in the case of their MBC (TABLE 4), Bacillus subtilis had the highest $(263 \mathrm{mg} / \mathrm{ml})$ compare to the Staphylococcus aureus $(131 \mathrm{mg} / \mathrm{ml})$. This could be attributed to the fact that Bacillus subtilis, being a spore-former, could produce spores. Spores are very resistant to adverse conditions such as the presence of antibacterial agents and can only be killed at extreme conditions such as very high quantity of antimicrobial agents. The higher MIC of Klebsiella pneumoniae $(263 \mathrm{mg} / \mathrm{ml})$ as compare to other Gram-negative bacteria $(66 \mathrm{mg} / \mathrm{ml})$ in this study (TABLE 3$)$ might be probably Klebsiella pneumoniae has been exposed more to antibiotics and has therefore acquired more resistance (or multi-resistance) to antibiotics. The antimicrobial activities of the sap on the tasted organisms as shown from the result of this study, confirms its use in treating antimicrobial infections like wound infection, itchy skin and skin eczema [12] and suggests that it could also be employed in the treatment of diseases caused by Klebsiella pneumoniae and Candida $\mathrm{sp}$.

\section{Conclusion}

In this age of increased emergence of pathogenic microorganisms that are resistant/ multi resistant to major class of antibiotics due to indiscriminate use of synthetic antimicrobial drugs, this study has opened more air in search for possible source for cheaper, effective new plant based drugs with better bioactive potential, and the plant sap can be used in this time of urgent and continuous need of exploration and development of new and better drugs. The study has evaluated both the MIC and the MBC of the sap, time kill assays is recommended for further work.

Because the sap is broad spectrum in action, it implies that the sap can be useful in antiseptic and disinfectant formulation as well as in chemotherapy if the active principle can be isolated. The antipseudomonal and anti-staphylococcal, anti-candidal activities of the sap of this plant can be further explored. 


\section{References}

[1] Jachak SM and Saklani A. Challenges and opportunities in drug discovery from plants. J. Curr. Sci. 92(1), 2007, 1251-1257.

[2] Racio MC, Rios JC, and Villar A. A review of some antimicrobial compounds isolated from medicinal plants. Phytotherapy Res 3(4), 1989, 117-125.

[3] Karaman L, Sahin F, Gulluce M, Ogutcu H, Sngul M, and Adiguzel A. Antimicrobial activity of aqueous and methanol extracts of Juniperus oxycedrus L. J Ethnopharmacol 85, 2003, 231-235.

[4] Schinor EC, Salvador MJ, Ito IY, and Dias DA. Evaluation of the antimicrobial activity of crude extracts and isolated constituents from Chresta scapigera. Brazilian J MIcrobiol 38, 2007, 145-149.

[5] Nino J, Navaez DM, Mosquera OM, and Correa YM. Antibacterial, antifungal and cytotoxic avtivities of eight Asteraceae and two Rubiaceae plants from Colombian biodiversity. Brazilian J MIcrobiol 37, 2006, 566-570.

[6] Essawi T, and Srour M. Screening of some Palestinian medicinal plants for antibacterial activity. J Ethanopharmacol 46, 2000, 343349.

[7] Iwu MW, Duncan AR, and Okunji CO. New antimicrobials of plant origin. In: J. Janick, (Ed.), Perspectives on New Crops and New Uses. (Alexandria, VA, ASHS Press, 1999) 457-462.

[8] Padua LS, Bunyapraphatsara N, and Lemmens RHMJ. Plant Resources of South-East Asia No (12)1. Medicinal and poisonous plant, 1 (Leiden, Backhuys Publishers, 1999) Antibacterial and Antifungal Activities of Jatropha multifida (Ogege)Sap against Some Pathogen

[9] Dehgan B. A review of Jatropha multifida Linn. Proc. Fla. State. Hort. Soc., 95, 1982, 277-280.

[10] Nayak BS, and Patel KN. An Appraisal. International Journal of Pharmaceutical Research, 1(3), 2009, 35-39.

[11] Kirtikar and Basu, Indian Medicinal Plant. 4, 1981, 2240-2247.

[12] Shu MFS, Bingtao L, and Gilbert MG. Jatropha. Fl. China, 11, 2008, 268-269.

[13] Kayode J, and Omotoyinbo MA, Research Journal of Botany, 3(3), 2008, 107-115.

[14] Yadav RNS, and Munin A. Phytochemical analysis of some medicinal plants. J. of phytology 3(12), 2011, 10-14.

[15] National committee for clinical laboratory standards, author, Methods for dilution, antimicrobial susceptibility tests for bacteria that grow aerobically. 5th ed., 2000, 30 .

[16] Atata R, Sani A, and Ajewole SM. Effect of stem back extracts of Enantia chloranta on some clinical isolates. Biokemistri. 15(2), 2003, 84-92.

[17] Shahidi Bonjar GH. Evaluation of Antibacterial properties of Iranian Medicinal plants against Micrococcus aureus, Serratia marcescens, Klebsiella pneunomiae and Bordella bronchoseptica. Asian Journal of Sciences. 3(1), 2004, 82-86.

[18] Prescott ML, Harley J, Donald P, and Klein A. Microbiology. 2nd edition. (U.S.A.: published by C. Brown Publishers, 1999$) 325$.

[19] Akinyemi KO, Oladapo O, Okwara CE, Ibe CC, and Fasure KA. Screening of crude extracts of six medicinal plants used in southwest Nigerian unorthodox medicine for antimethicillin resistant Staphylococcus aureus activity. BMC Complementary and Alternative Medicine. 5, 2005, 6 .

[20] Olukoya DK, Odugbemi TO, and Bamgbose SOA. Some aspects of traditional therapy of Gonorrhoea in Lagos, Nigeria. Journal of Research in Ethno-Medicine. 1, 1986, 26-29.

[21] Basri DF, and Fan SH. The potential of aqueous and acetone extracts of galls of Quercus infectoria as antibacterial agents. Indian Journal of Pharmacology 37(1), 2005, 26-29.

[22] Meyer JJM, and Afolayan AJ. Antibacterial activity of Helichrysum aureonitens (Asteraceae). Journal of Ethnopharmacology 47(2), 1995, 109-111.

[23] Tortora GJ, Funke BR, and Case CL. Microbiology: An Introduction, Benjamin Cummings. (San Francisco, 2001)

[24] Susana J, Vetúria LO, Moacir GP, Jan S, Raimundo B, Alexsandro B, and Artur SJ. Antimicrobial activity of wax and hexane extracts from Citrus spp. peels. J. Bioline International 102(6), 2007, 681-685 